\title{
The Development of E-Book Based on Project Based Learning on the Plant Anatomy Structure Material
}

\author{
Desy Muwaffaqoh ${ }^{1}$, Tjandra kirana ${ }^{2}$, dan Fida Rachmadiarti ${ }^{3}$ \\ 1,2,3Universitas Negeri Surabaya, Surabaya, Indonesia
}

\begin{tabular}{|c|c|}
\hline 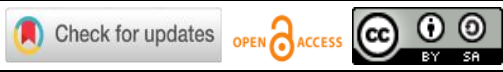 & DOI : https://doi.org/10.46245/ijorer.v2i4.127 \\
\hline Sections Info & ABSTRACT \\
\hline $\begin{array}{l}\text { Article history: } \\
\text { Submitted: June 29, } 2021 \\
\text { Final Revised: July 7, } 2021 \\
\text { Accepted: July 11, } 2021 \\
\text { Published Online: July 31, } 2021\end{array}$ & $\begin{array}{l}\text { Problem solving skills are needed by students to solve problems that arise in } \\
\text { everyday life. Innovation in learning is needed so that students can achieve } \\
\text { the basic competencies and apply } 21 \text { st-century skills, in the form of interactive, } \\
\text { collaborative learning models. One of the innovations is using the Project- } \\
\text { Based Learning learning model with the E-book of plant anatomy structures. }\end{array}$ \\
\hline $\begin{array}{l}\text { Keywords: } \\
\text { E-book } \\
\text { Project Based Learning (PjBL) } \\
\text { Plant anatomy structures } \\
\text { Problem solving }\end{array}$ & $\begin{array}{l}\text { This study aims to develop an E-book of PjBL-based plant anatomy structures } \\
\text { to practice problem-solving skills which are declared valid in terms of } \\
\text { theoretical and empirical aspects. The theoretical aspect is viewed from the } \\
\text { results of the validity. Empirical aspects in terms of learning outcomes, } \\
\text { student responses, and readability. The development model used is } 4 \mathrm{D} \text {. The }\end{array}$ \\
\hline 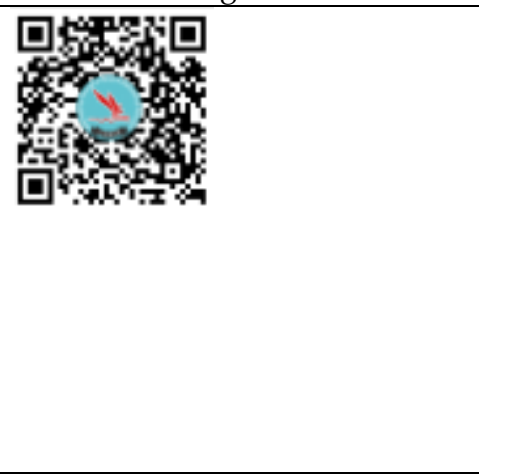 & $\begin{array}{l}\text { research was carried out at the UNESA Postgraduate Program in June-August } \\
\text { 2020. The target of this research was an online E-book on the structure of plant } \\
\text { anatomy based on Project Based Learning which was tested on ten students of } \\
\text { Muhammadiyah } 1 \text { Gresik senior high school in February 2021. The } \\
\text { instruments used were validation sheets, student response sheets, and fry } \\
\text { chart sheets. The data were analyzed descriptively quantitatively. The results } \\
\text { showed that the PjBL-based E-book of plant anatomical structures was } \\
\text { theoretically feasible based on the validation results obtained an categories } \\
\text { very valid and empirically feasible based on student learning outcomes (N- } \\
\text { gain of moderate categories). Based on this description, a PjBL E-book of plant } \\
\text { anatomy structures to train students' problem-solving skills is feasible } \\
\text { theoretically and empirically. }\end{array}$ \\
\hline
\end{tabular}

\section{INTRODUCTION}

The growth of the globalization era in the 21st century has become a competitive factor for some countries in the world to face the improvement of science and technology. Many countries have seen revolutionary changes with the implementation of science and technology. Technology and data are developing rapidly along with the era development, so that everyone must be able to master the area of life, health, and other problems that are faced by modern citizens. The result of this is the increasing graduate students' competence in the work field. There are many jobs that require a large level of expertise such as critical thinking, reasoning, decision making and skills in dismantling a problem or Problem Solving. 21st-century skills are high-level skills that must be owned by humans to be able to work in the real world and able to face the challenges of the 21st-century (Wijaya et al, 2016). Human Resources in the 21st-century national education paradigm must have several competencies, namely: 1) critical thinking and problem-solving skills 2) communication and collaboration skills 3) the ability to create and update 4) information and communication technology literacy 5) contextual learning ability, and 6) information and media literacy skills (Nugroho, 2015). According to the Ministry of Education and Culture (2017) skills in the 21st century are 4C (Critical thinking, Collaborative, Communicative, and Creative) and integrating HOTS questions. 
The Development of E-Book Based On Project Based Learning On The Plant Anatomy Structure Material

Based on the description, problem-solving skills must be owned by a person or student to be able to carry out his life in society, a person will easily solve problems in his life if he has good problem-solving skills. In this era human resources are trained to have skills in order to face the world, and succeed in an increasingly complex and uncertain life (Rahmawati, 2021). Teachers also need to pay attention to students' initial skills, problem solving skills in order to increase and facilitate the process of defining the problem solution (Hidayatullah, 2020). Problem-solving skills are needed by students to solve every problem that appears in everyday life. This matter is conformable with the research conducted by Gunantara (2014), problem-solving skills are abilities that students have in solving problems and implementing them in everyday life. The Ministry of Education and Culture of the Republic of Indonesia (2016) confirms that curriculum changes in the Indonesian education system are a form of response to the demands of the 21st century. Learning that implements the 2013 Curriculum is very recommended to be learning that involves students actively, so the teaching and learning process is no longer teacher-centered (teacher-center) but student-centered. In addition, the principle of the 2013 curriculum is learning that not just makes the teacher the only source of learning but learns from various sources (Albantani, 2015).

The biggest sources of learning biology are nature and the environment. One example of biology learning material that can be utilized from various sources and correspond with the 2013 curriculum and 21st century is the basic competence (KD) material 3.3 Analyzing the relationship between cell structure in plant tissues and organ functions in plants and KD (Basic Competence) 4.3 Presenting data from observations of the structure of tissues and organs in plants. Innovation in learning is needed so that students can achieve KD (basic competence) and apply 21st-century skills in the form of interactive, collaborative learning models and help students improve problem-solving skills in everyday life. One of these learning innovations uses the PjBL (project-based learning) learning model with an E-book on the structure of plant anatomy.

Project-based learning model PjBL (Project-Based Learning) is learning that uses a problem as one of the first steps to build knowledge based on real life (Safaruddin et al., 2020). This is in line with Sumarmi (2012) which states that project-based learning is authentic learning, where this learning is very systematic to develop a real product and task. At the end of project-based learning, students will independently develop problem-solving. Komalasari (2011) asserts that the Project-Based Learning-based learning model trains students to work independently and build their knowledge to understand a concept and students can create a real product.

The PjBL Project-Based Learning model has advantages including increasing students' ability in problem-solving, training students to be more active in solving complicated and complex problems, training in communication skills, and increasing collaboration in project-based learning that is group (Hosnan, 2014, Safaruddin et al., 2020). Increasing students' ability to produce contextual work individually or in groups, it is highly recommended to use a learning approach that can produce problem-based work or Project-Based Learning (Brassler and Dettmers, 2017). Project Based Learning is able to facilitate students to face the demands of 21st century skills (Riyadi and Rahayu, 2017). Some research on PjBL showed that PjBL can have positive impact on education and increase student motivation, emphasizing student-centred and experiential approach to comprehensive education (Handayani, 2021). Students' 
The Development of E-Book Based On Project Based Learning On The Plant Anatomy Structure Material

problem-solving abilities need to be trained continuously so that students can solve their problems (Nirwana, 2021).

Based on Rahmawati's research (2021) regarding problem-solving skills, problemsolving skills play a role in the process of finding solutions by involving higher-order thinking skills to overcome the problems they face and will help students prepare students as innovators and highly knowledgeable. From the studies above, it can be seen that the application of the project-based learning model has a positive value on student learning outcomes and activities. Based on this description, the relationship between project-based plant anatomy structure E-books ( $\mathrm{PjBL}$ ) to practice problemsolving skills can be seen from project-based learning steps such as determining a project that requires students to ask questions where this activity is one way to practice skills. problem-solving, then students will design a project so that students are required to make a problem formulation. The plant anatomy structure e-book is equipped with steps that make it easy for students to apply PjBL learning. Based on the explanation that has been described, the researcher proposes the "Development of an E-book on the structure of plant anatomy based on PjBl (Project Based Learning) to practice student problem-solving skills". The research is expected to have several benefits in learning as a new learning model that can train students' problem-solving skills and provide input to Biology teachers learning models that can create an interesting learning atmosphere and activate students during the learning process.

\section{RESEARCH METHOD}

\section{General Background}

This research is development research using the $4 \mathrm{D}$ model. This research was carried out from June 2020 to February 2021. The development stage was carried out at the Postgraduate UNESA (Figure 1).

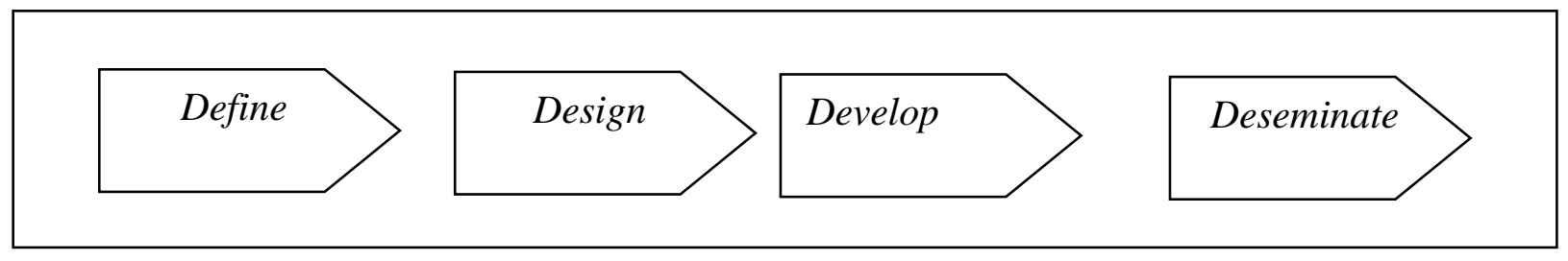

Figure 1. 4-D development model (Thiagarajan, 1974).

\section{Sample / Participants / Group}

A limited trial was conducted by involving ten students of XI MIPA class Muhammadiyah 1 Gresik senior high school online using Google meet and WhatsApp Group. The trial design used is one group pre-test-post test.

\section{Instrument and Procedures}

The theoretical feasibility of the E-book is assessed based on the validity of the E-book by three expert lecturers. The feasibility of the developed E-book in terms of 3 components, namely: content feasibility components, presentation feasibility, and language feasibility. The empirical feasibility of E-book is obtained based on the results of the analysis of readability, learning outcomes, and responses of E-book users. The instruments used in this study were validity sheets, problem-solving skills test sheets, 
The Development of E-Book Based On Project Based Learning On The Plant Anatomy Structure Material

student response sheets, and readability sheets using the fry chart. Student responses and student learning outcomes (pretest-posttest) were collected using Google forms.

\section{Data Analysis}

The validation assessment uses a Likert 1-4 measurement scale. The data is then analyzed using the following formula:

$$
\text { Score }=\frac{\sum \text { total score of each component of validators }}{\sum \text { number of validators }}
$$

The criteria score obtained then interpreted using the validity score interpretation criteria.

Table 1. Criteria for validity.

\begin{tabular}{cc}
\hline Average score (\%) & Category \\
\hline $0-1,75$ & Not valid \\
$1,75-2,50$ & Quite valid \\
$2,50-3,25$ & Valid \\
$3,25-4,00$ & Very valid \\
\hline & (Adapted from Riduwan, 2013)
\end{tabular}

The students' responses used the Guttman model criteria with the answers "Yes" and "No". The data is then analyzed using the following formula:

$$
\% \text { Student response }=\frac{\text { ¿answer score }{ }^{\mathrm{I}} \text { yes }^{\mathrm{m}}}{\sum \max \text { score }} \times 100 \%
$$

The percentage of students' positive responses obtained was then interpreted using the criteria for interpreting students' positive responses.

Table 2. Criteria for interpretation of student responses.

\begin{tabular}{cc}
\hline Average score (\%) & Category \\
\hline $0-40$ & Ineffective \\
$41-55$ & Less effectiv \\
$56-70$ & Effective enough \\
$71-85$ & Practical \\
$86-100$ & Very effective \\
\hline
\end{tabular}

The assessment of student learning outcomes is measured using a learning outcome test that is used to determine student learning outcomes, which contains a collection of questions referring to problem solving indicators that have been developed including defining problems, examining problems, planning solutions, implementing plans that have been made and evaluate. Learning outcomes test (learning outcomes are given at the first meeting as a pretest and the last meeting of learning activities) as a posttest after using the E-book. Analysis of student learning outcomes pays attention to the completeness of indicators that be achieved in learning with the following calculations:

$$
\text { Completeness indicator }=\frac{\sum \text { students achieved indikator }}{\sum \text { students }} \times 100 \%
$$


Table 3. Criteria for interpretation of student learning outcomes completeness.

\begin{tabular}{cc}
\hline Average score (\%) & Category \\
\hline $0-40$ & Not very good \\
$41-55$ & Not good \\
$56-70$ & Enough \\
$71-85$ & Good \\
$86-100$ & Very good \\
\hline
\end{tabular}

Completeness is said to be good based on indicators if it gets a percentage of $\geq 71 \%$. The data is then analyzed to determine the improvement of student's initial abilities before and after learning. This increase is known through N-Gain analysis, then compared with categories by Hake (1999) namely normalized N-Gain, namely the comparison of the actual N-Gain score with the maximum N-Gain score. This can be expressed by the formula :

$$
<\mathbf{g}>=\frac{\%<S f>-\%<S i>}{\%<S \text { maks }>-\%<S i>} \times 100 \%
$$

Table 4. Normalized N-gain criteria.

\begin{tabular}{cc}
\hline Normalized N-Gain Range & N-Gain Criteria \\
\hline $\mathrm{g}<0,30$ & Low \\
$0,30 \leq \mathrm{g} \leq 0,7$ & Average \\
$\mathrm{g}>0,70$ & High \\
\hline
\end{tabular}

(Hake, 1999)

To find out the correlation between problem-solving and PjBL based on student learning outcomes, it can be known based on the r-value of the results of correlation analysis. The value of $r$ is then interpreted to estimate the strength of the correlation relationship, as shown in the following Table 5.

Table 5. Table of interpretation of pearson's $\mathrm{r}$ value correlation analysis results.

\begin{tabular}{cc}
\hline$r$ Value Interval & Interpretation \\
\hline $0,001-0,200$ & Very weak correlation \\
$0,201-0,400$ & Weak correlation \\
$0,401-0,600$ & The correlation is quite strong \\
$0,601-0,800$ & Strong correlation \\
$0,801-1,00$ & Very strong correlation \\
\hline
\end{tabular}

The readability analysis of the developed E-book is calculated by counting the number of sentences and the number of syllables in 100 words and then converted into a fry graph. Based on the results of this readability analysis, it will be known the suitability of the E-book with the student level. The theoretical and empirical feasibility data are then analyzed quantitatively descriptive.

\section{RESULTS AND DISCUSSION}

The result of this development research is an E-book of PjBL-based plant anatomy structures to train students' problem-solving skills that are theoretically and empirically valid. The e-book on the structure of plant anatomy has a display that can be accessed 
The Development of E-Book Based On Project Based Learning On The Plant Anatomy Structure Material

online using the fliphtml5.com application which can be accessed for free, using the book antiqua 12pt font, white writing background. The e-book has features that relate to PjBL learning, namely Bio-Instruction, Bio-Project. The contents of the E-book on the structure of plant anatomy include project-based usage instructions, project activity procedures, user activities, link feature to connect to YouTube, a summary of material on the anatomical structure of plants, and ten plants that have observations of plant organ sections. E-books are electronic books that can be read on laptops and can connect various features such as photos, videos, music and allow students and teachers to interact actively (Muhammad, 2017). Currently, there are many learning resources in the form of books, which were originally in the form of text books, but developed into electronic books (e-books) (Restiyowati, 2012). Electronic school books are one form of teaching materials that are widely used today (Searmadi, 2016).
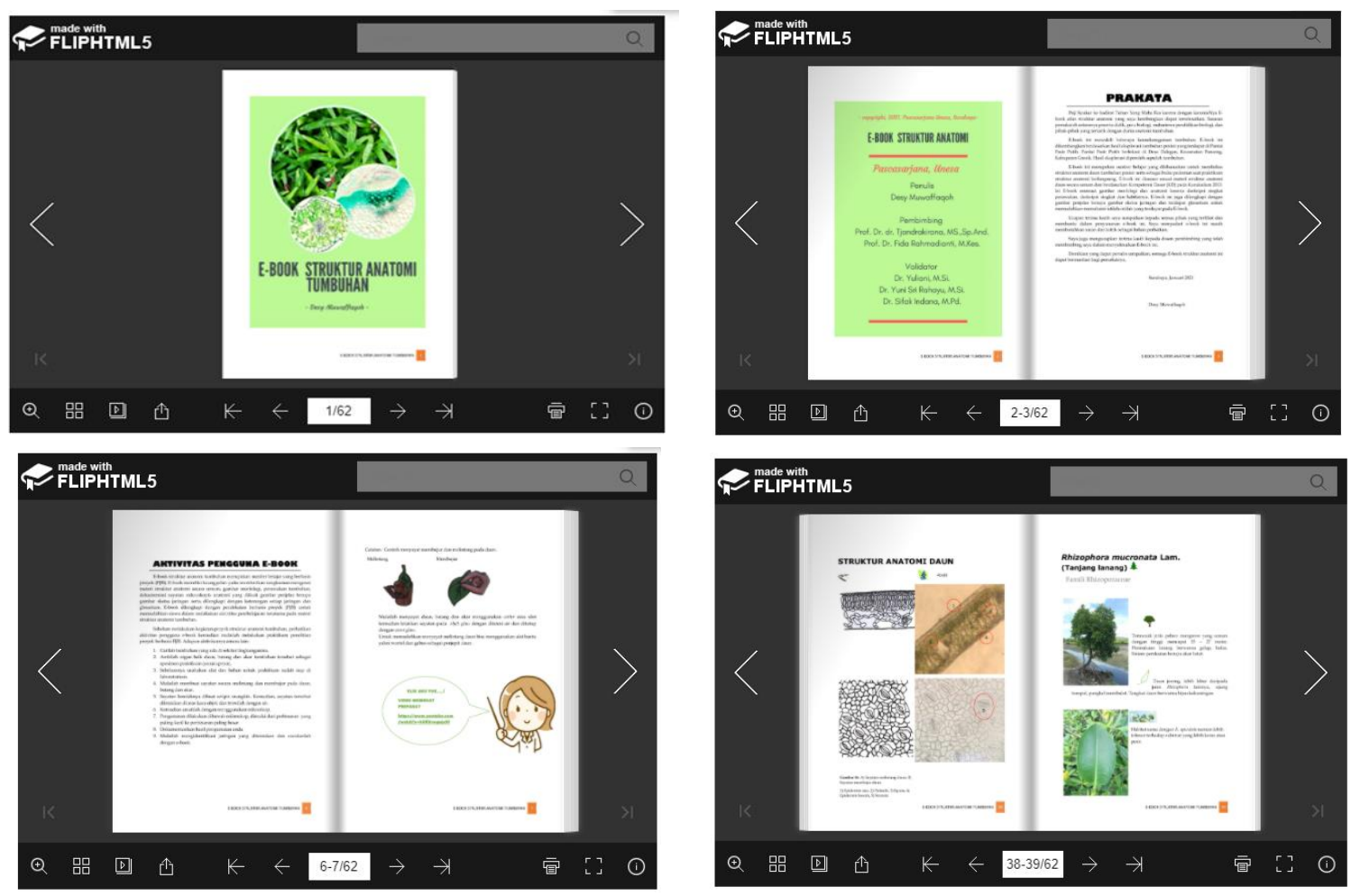

Figure 2. Display of plant anatomy structure e-book.

The theoretical feasibility based on the recapitulation of the assessments by the three validators shows that the E-book is very valid. The validity of the E-book viewed from 3 components, namely the components of presentation feasibility, content feasibility, and language feasibility (Table 6). This is conformable with the textbook standards according to BSNP (2014) and Minister of Education and Culture Regulation No. 8 of 2016 concerning books used by education units.

Table 6. Results recapitulation of the E-book validation of plant anatomy structures.

\begin{tabular}{|c|c|c|c|}
\hline \multirow[t]{2}{*}{ Aspects of assessment } & $\begin{array}{c}\text { Validatiol } \\
\text { score }\end{array}$ & \multirow[t]{2}{*}{ Average } & \multirow[t]{2}{*}{ Category } \\
\hline & $\begin{array}{ll}\text { V1 } & \text { V2 } \\
\end{array}$ & & \\
\hline
\end{tabular}

Material coverage and accuracy

A. Eligibility Content 
The Development of E-Book Based On Project Based Learning On The Plant Anatomy Structure Material

\section{Aspects of assessment}

1 In accordance with the learning objectives

2 Easy to understand

3

\section{Validation}

\begin{tabular}{ccc}
\multicolumn{3}{c}{ score } \\
\hline 4 & 3 & 4
\end{tabular}

$\begin{array}{lll}4 & 3 & 4\end{array}$

$4 \quad 4 \quad 4$

\section{Recency}

4 The material is in accordance with the current development of biological science

5

Has component linkages that reflect current events or conditions

6 Using the library less than last 10 years

\section{Project-based learning}

7

Include activities to formulate a problem statement

8 Include activities to make a plan for implementing project

activities

9 Include activities to collect observation data

valid

$\begin{array}{ccccc}4 & 4 & 4 & 4 & \begin{array}{c}\text { Very } \\ \text { valid } \\ 4\end{array} \\ & 4 & 4 & 4 & \begin{array}{c}\text { Very } \\ \text { valid }\end{array} \\ 4 & 3 & 4 & 3,6 & \begin{array}{c}\text { Very } \\ \text { valid }\end{array}\end{array}$

$\begin{array}{lllll}4 & 4 & 3 & 3,6 & \text { Very }\end{array}$

valid

Very

valid

Very

valid

Very

valid

\section{B. Feasibility of presentation}

\section{Sentence arrangement}

1 Coherent presentation based on concept

2

Student centered

3 Simple discussion

Use of symbols, terms and words

\section{4}

In the sketch image there is a name as identity

5 In the table there are numbering/naming as identity

6 The illustrations according to material

\begin{tabular}{|c|c|c|c|}
\hline 3 & 3 & 3 & 3 \\
\hline 4 & 4 & 4 & 4 \\
\hline & 4 & 4 & 4 \\
\hline
\end{tabular}

$\begin{array}{lllll}4 & 4 & 4 & 4 & \text { Very }\end{array}$

valid

Very

valid

Very

valid

Very

valid

Average aspect

C. Language eligibility

\section{Presentation technique}

1

Sentences easy to understand

2

Use logical sentences

3 Standardization of terms in sentences

Material presentation support

4

5 Use the correct language

6 Using the correct language, foreign/scientific names, and consistent symbols

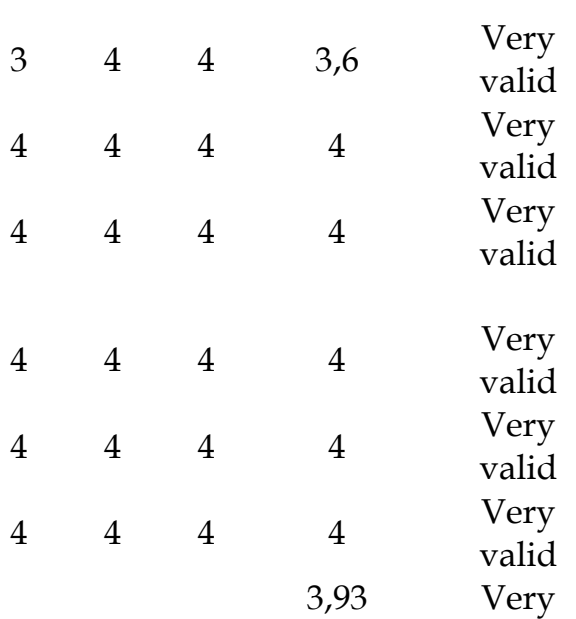


The Development of E-Book Based On Project Based Learning On The Plant Anatomy Structure Material

\begin{tabular}{|c|c|c|c|}
\hline Aspects of assessment & $\begin{array}{c}\text { Validation } \\
\text { score }\end{array}$ & Average & \\
\hline & & & valid \\
\hline Average amount & & 3,83 & $\begin{array}{l}\text { Very } \\
\text { valid }\end{array}$ \\
\hline
\end{tabular}

The results of the recapitulation of the validation of Project-Based Learning based Ebooks in Table 6 show that of the 21 available assessment criteria and three aspects namely content, presentation, language, it was found that all assessment criteria were scored in a very valid category with the percentage of eligibility for Project-based Ebooks. Based Learning obtained an average of 3.83. Based on the percentage value of the feasibility of the E-book, it shows that the E-book based on Project Based Learning to practice Problem Solving on the material of plant anatomical structures has very valid criteria. The project-based plant anatomy structure e-book is said to be theoretically feasible, one of which is based on the feasibility aspect of the content contained in the Bio-Instruction feature which contains instructions for use which aims to make it easier for students to understand how to use a project-based E-book, for example on a page containing instructions for use. E-book, procedures for activities and activities of E-book users. This is conformable with the scaffolding theory which states that assistance is given to students to learn to solve problems. The information in the ebook must be clear to make it easier for students to understand the content of the material and instructions for using the e-book (Nurhasikin, 2019). The encouragement is in the form of instructions, warnings, describing problems into solving steps, sharing examples, and other actions that allow students to learn independently (Taylor, 1993).

Project-based e-books said to be theoretically feasible also based on the feasibility of the content contained in the Bio-Project feature which presents project assignments using PjBL completion steps consisting of Question, Plan, Schedule, Monitor, Assess and Evaluate (The George Lucas Education Foundation, 2005). At the Bio-ProjectQuestion stage, pictures, readings, and information are presented to guide students in finding the theme of the project to be developed, for example on the Question page which is the first stage of project completion, students are asked to read insight into exploring phenomena about the problem of adaptation of mangrove plants and differences in environmental habitats. plants, then students are asked to determine the fact that mangrove plants grow in a dry stress environment and have different anatomical structures from terrestrial plants, and the topic of the problem and make a problem formulation related to the phenomena in the reading. One of problem formulations made by students was "How are the anatomical structures of terrestrial plants different from those of mangrove plants?". Wahida (2015) argues that by asking questions or discourses related to the concepts to be studied, students can understand problems and think about products by relating them to everyday life. This is similia with Kubiatko and Vaculoca (2011) project-based learning is learning that develops resources to find information and evaluate results in completing the project. According to Serin (2019), PjBL learning in the educational process provides students with opportunities to build knowledge in real contexts, where the main idea in PjBL is to provide opportunities for students to investigate problems in the real world that will allow students to gain new knowledge, PjBL provides opportunities for students to explore their abilities in critical thinking, problem-solving, as independent work.

The developed e-book also includes a Bio-Info feature that presents short material concepts regarding plant anatomical structures, plant morphology images, plant 
The Development of E-Book Based On Project Based Learning On The Plant Anatomy Structure Material

anatomy drawings, and sketches explaining plant anatomy. The morphology, anatomy, and sketch images in the E-book are original images that were directly documented by the researcher. A good picture is showing objects clearly and accurately, photo lighting is sufficient (no noise or spots in the photo), the composition or object layout settings support (photo message is conveyed), and photos are not overlighted or excess light. This is conformable with Sadiman's (2008) question which states that a good photo is an authentic and representative photo. Photos are a source of accurate information, in the developed E-book, the photos displayed contain important information that can help students to obtain information. Displays in e-books that contain phenomena, pictures, videos, hyperlinks, and animations can help students understand the material and make e-books have a high level of interest (Rosida, 2017). Photos include variations of the multimodal text that can be used as a source of accurate information. E-books that contain media as pictures, graphics, and videos make easier for students to learn the material and attract students to increase their interest in learning (Lestari, 2018).

Research on the development of project-based plant anatomy structure E-books is not only assessed from theoretical feasibility but also empirical feasibility. Empirical feasibility is assessed based on the results of the analysis of learning outcomes, readability, and user responses. Student responses are responses from students after using the E-book that has been developed. Student responses are used to find out responses about the developed E-book. Low student response to textbooks can hinder learning activities that have an impact on the process of receiving learning materials. As a result, learning becomes less effective and less optimal (Murray \& Rockowitz, 2017). In general, based on the assessment of readability, language, appearance, interesting concepts, and Project-Based Learning activities, students gave a positive response to the developed E-book because, in the preparation of the E-book, efforts have been made to make the E-book interesting. The student response sheet was filled out by 10 students after carrying out learning activities, the response questionnaire was filled out by choosing a yes or no answer through the Google form that had been given to students. Student responses to all aspects obtained a score of $98.5 \%$ which indicates that students' responses to the developed E-book are "very positive".

Project-Based Learning-based e-books on plant anatomy structures to train students' problem-solving skills were also assessed from empirical feasibility based on student learning outcomes. Data on student learning outcomes were obtained using pre-test and post-test sheets. The student learning outcomes test sheet contains questions that refer to indicators and learning objectives as well as aspects of problem-solving skills. The data recapitulation of student learning outcomes is presented in the form of Table 7.

Table 7. Results of the recapitulation of student learning outcomes.

\begin{tabular}{cclccc}
\hline Name & Pretest & Category & Posttest & Category & N-gain \\
\hline Student 1 & 55 & Incomplete & 75 & Complete & 0,44 \\
Student 2 & 20 & Incomplete & 45 & Incomplete & 0,31 \\
Student 3 & 25 & Incomplete & 50 & Incomplete & 0,33 \\
Student 4 & 45 & Incomplete & 60 & Incomplete & 0,27 \\
Student 5 & 0 & Incomplete & 30 & Incomplete & 0,3 \\
Student 6 & 20 & Incomplete & 50 & Incomplete & 0,37 \\
Student 7 & 45 & Incomplete & 75 & Complete & 0,54 \\
Student 8 & 50 & Incomplete & 55 & Incomplete & 0,1 \\
Student 9 & 60 & Incomplete & 75 & Complete & 0,37 \\
\hline
\end{tabular}


The Development of E-Book Based On Project Based Learning On The Plant Anatomy Structure Material

Table 7. Results of the recapitulation of student learning outcomes.

\begin{tabular}{cccccc}
\hline Name & Pretest & Category & Posttest & Category & N-gain \\
\hline Student 10 & 70 & Incomplete & 80 & Complete & 0,33 \\
\hline Sum & 390 & & 595 & & \\
\hline Average & 39 & & 59,5 & & 0,33 \\
\hline
\end{tabular}

Table 7 shows the results of the pre-test and post-test of class XI students of Muhammadiyah 1 Gresik senior high school as many as 10 students. The results of the pre-test showed that all students did not complete, while the results of the post-test showed that 4 students completed and 6 other students did not completed. Overall improvement in learning outcomes increased even though only four students completed. The N-gain results show that the students' pre-test and post-test results are 0.33 and are included in the medium category.

Based on the learning outcomes that have been implemented, the data on the mastery learning outcomes will be analyzed using a correlation test. A correlation test is used to determine the relationship between Problem Solving skills and Project-Based Learning learning indicators. Table 8 is a table of correlation test results.

Table 8. Correlation test post-test completeness indicators (pre-test and post-test).

\begin{tabular}{clcc}
\hline Variable & \multicolumn{1}{c}{ Description } & Pre-test & Post-test \\
\hline Pre-test & Pearson Correlation & 1 & 0,982 \\
& Sig. (2-tailed) & & 0,003 \\
& N & 5 & 5 \\
Post-test & Pearson Correlation & 0,982 & 1 \\
& Sig. (2-tailed) & & \\
& N & 0,003 & 5 \\
& & 5 & 5 \\
\hline
\end{tabular}

Based on Table 8 , the significant value obtained is 0.003 . Because the significant value is $<0.05$, there is a relationship between problem-solving skills and the completeness of Project-Based Learning indicators based on student learning outcomes. The interpretation of a very strong positive relationship between problem-solving skills and Project Based Learning can be seen from the number of correlation coefficients or the value of $\mathrm{r}=0.982$. Thus it can be concluded that the relationship between problemsolving and Project-Based Learning based on student learning outcomes is very strong, problem-solving and $\mathrm{PjBL}$ also have a "positive or unidirectional" relationship pattern.The mastery of student learning is also related to the mastery of the pre-test and post-test learning indicators, most of the students are weak in the indicators of planning and solving problem-solving solutions. Based on Saputri and Mampouw (2018) that before compiling a problem-solving plan, the subject must plan what stages are needed and look for references to concepts and theories that support problem-solving. The advantages of Project Based Learning can bridge students to develop creativity through problem solving activities in the form of projects (Kusumaningrum, 2016).

The highest average indicator is examining and understanding the problem, this happens because students can identify problems, understand the problems at hand so that students can identify the main ideas of existing problems. This is supported by the opinion of Mahardiningrum and Ratu (2018) which states that in the step of examining and understanding problems, interpretation skills are needed so that the subject can 
handle and understand the existing problems. Levine and Mosier (2012) say that by using Project-Based Learning in the classroom, students can develop problem-solving skills with higher-order thinking and have a positive effect on content knowledge.

E-book empirical eligibility criteria are not only measured by learning outcomes based on pre-test and post-test cognitive questions but also can be viewed from the work that has been done by students. Students make project results in the form of power points as a form of understanding of the concepts they get from an observation. Aprillia said (2014) the project is a complex task where students are in the main role to find and solve problems, make decisions, investigate, work independently and produce tangible products. One of the learning approaches is improve student competence from various researches has been tried is project-based education. Interaction can occur efficiently in PjBL by using an inquiry process by focusing on student participants to create products that are applicable and related to everyday life (Arizona et al, 2020). The implementation of $\mathrm{PjBL}$ proven that the learning model makes students meaningful learning process, namely learning that is raised based on constructivism. Students allowed to dig their data through various sources directly, communicate the results of their activities to others, work in groups, share ideas with others, and various other activities (Antika, 2017). The project-based PjBL model is oriented towards a series of activities to create a certain concept in which students build their knowledge with an experiment, also construct a research project to deal with a problem-solving process in small groups to discuss and design problem-solving in daily life by practicing scientific methods. (Komarudin, 2020). Project-based learning is an innovative approach that focuses on contextual learning through complex activities. Complex activities are based on challenging questions, problems and require students to design, solve problems, make decisions and provide opportunities to work independently (Setiawan, 2020).

Project-Based Learning based e-books on plant anatomy structures to train students' problem-solving skills were also assessed from empirical feasibility based on the results of readability analysis. E-book readability analysis using the fry chart. The level of readability can also be used to predict the level of comprehension and reading errors. The suitability of the textbook to the readability rating will help someone understand the text/reading that he is reading. However, if the textbook does not match the readability rating with a person's level, then that person will have difficult understanding the book he is reading. The level of readability of a book can be measured using a Fry diagram (Zamanian and Heydari, 2012). Readability is influenced by the sentences's length and difficult words that are used (Sari, 2017). Researchers used five samples in conducting a readability analysis so that the results obtained were accurate. 


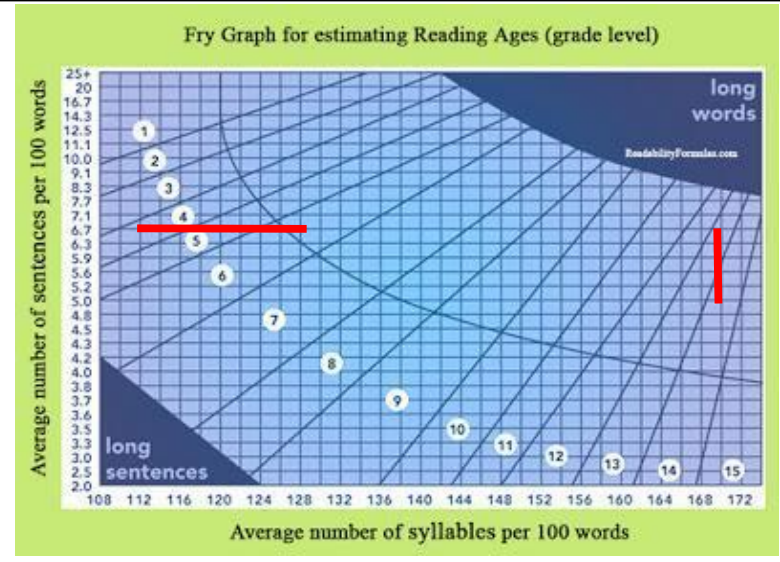

Figure 3. Fry graph e-book readability test.

The results of the analysis show that the E-book on the structure of plant anatomy is suitable for all middle-level circles. A good textbook is a textbook that conforms to the eligibility standards set by BSNP to have a high readability level for students so that students can easily understand what they are reading. Readability level is whether or not a reading is easy to read and understand (Zamanian and Heydari, 2012). The book has a readability level that is suitable for the student's grade level so that students more easily master the content data contained in the book (Himalaya, 2016). The designations that are used must be easy to be understood and match to the student's assumptions, if students face some difficulties while reading the text that makes them feel less interested in reading since the data which they are looking for is not found (Fatin, 2017). Therefore, based on the results of the data obtained, although the calculation results show levels of 8,9,10, and 11, the relevant levels are suitable for use for grades 7,8,9 and grades 10, 11, and 12. plants suitable for all categories of middle students. Learning teaching materials that have been made practically will make students easier during learning process and make students interested in understanding the material which is being taught (Nyeneng, 2018).

\section{CONCLUSIONS}

Based on the description of the research question, research objectives, research results, and the discussion, it is concluded that to produce an E-book of plant anatomy structures based on Project Based Learning to train students' Problem Solving skills that are theoretically and empirically feasible. The development of this e-book can be implied by being used as one of the supporting media for Biology subjects on plant anatomical structures, one of the media to support students in practicing problem solving skills. The selection of the right learning method can affect student learning outcomes, there are differences in the pretest learning outcomes before using the e-book and the posttest after using the e-book. This research is far from perfect word and it might occur beyond the ability and willingness of the author which can affect the results of this study. The author suggests that it is necessary to conduct similar e-books development such as with different materials.

\section{ACKNOWLEDGEMENTS}

The researcher would like to thank lecturer Dr. Yuliani, M.Si. Dr. Sifak Indana, M.Pd and Dr.sc.agr.Yuni Sri Rahayu, M.Sc., as validators who have provided corrections and 
The Development of E-Book Based On Project Based Learning On The Plant Anatomy Structure Material

suggestions for this E-book and students of class XI MIPA Muhammadiyah 1 Gresik senior high school who have been willing to help this research.

\section{REFERENCES}

Albantani, A. M. (2019). Social media as alternative media for arabic teaching in digital era. ALSINATUNA, 4(2), 148-161. doi.org/10.28918/alsinatuna.v4i2.2043

Antika, R. N., \& Nawawi, S. (2017). Pengaruh model project based learning pada mata kuliah seminar terhadap keterampilan berpikir kreatif mahasiswa. Jurnal Pendidikan Biologi Indonesia, 3(1), 72-79.

Aprillia, Y. D., Indah, N. K., \& Indana, S. (2014). Validitas lks berorientasi project based learning pada materi keanekaragaman hayati kelas X. BioEdu: Berkala Ilmiah Pendidikan Biologi, 3(3). 656-661.

Arizona, K., Abidin, Z., \& Rumansyah, R. (2020). Pembelajaran online berbasis proyek salah satu solusi kegiatan belajar mengajar di tengah pandemi Covid-19. JIPP: Jurnal Ilmiah Profesi Pendidikan, 5(1), 64-70. doi.org/10.29303/jipp.v5i1.111

Bradley-Levine, J., \& Mosier, G. (2014). Literature review on project-based learning. University of Indianapolis Center of Excellence in Leadership of Learning.

Brassler, M., \& Dettmers, J. (2017). How to enhance interdisciplinary competenceinterdisciplinary problem-based learning versus interdisciplinary project-based learning. Interdisciplinary Journal of Problem-Based Learning, 11(2), 12. doi.org/10.7771/1541-5015.1686

Education, B. S. N. (2014). Academic Papers for Assessment Instruments for Feasibility Textbooks for Graphics. National Education Standards Agency.

Fatin, I. (2017). Keterbacaan buku teks bahasa indonesia kelas x kurikulum 2013 edisi revisi 2016 dengan formula FRY. BELAJAR BAHASA: Jurnal Ilmiah Program Studi Pendidikan Bahasa dan Sastra Indonesia, 2(1). doi.org/10.32528/bb.v2i1.643

Gunantara, G., Suarjana, I. M., \& Riastini, P. N. (2014). Application of problem based learning model to improve math problem solving ability of fifth grade students. Mimbar of PGSD Undiksha, 2(1). doi.org/10.23887/jjpgsd.v2i1.2058

Hosnan, M. (2014). Pendekatan saintifik dan kontekstual dalam pembelajaran abad 21. Bogor: Ghalia Indonesia.

Hake, R. R. (1999). American educational research association's division D, measurement and research methodology: Analyzing change-gain scors. America

Handayani, D., Winarni, E. W., Sundaryono, A., \& Firdaus, M. L. (2021). Implementation of project-based learning model with edmodo application in the capita selecta chemistry course. IJORER: International Journal of Recent Educational Research, 2(2), 184-195. doi.org/10.46245/ijorer.v2i2.90

Hidayatullah, R. S., Ariyanto, S. R., Mubarok, H., \& Yohannes, A. (2020). Collaborative problem-based learning: an analysis of problem-solving skills in vocational schools. IJORER: International Journal of Recent Educational Research, 1(3), 209-217. doi.org/10.46245/ijorer.v1i3.62

Himala, S. P. T., Ibrahim, M., \& Fitrihidayati, H. (2016). Keterbacaan teks buku ajar berbasis aktivitas pada materi ruang lingkup biologi kelas X SMA. BioEdu: Berkala Ilmiah Pendidikan Biologi, 5(3), 445-448.

Kemendibud. (2017). Panduan Impementasi Kecakapan Abad 21 Kurikulum 2013 di Sekolah Menengah Atas. Jakarta: Kementrian Pendidikan dan Kebudayaan Indonesia. 
The Development of E-Book Based On Project Based Learning On The Plant Anatomy Structure Material

Komarudin, K., Puspita, L., Suherman, S., \& Fauziyyah, I. (2020). Analisis Pemahaman Konsep Matematis Peserta Didik Sekolah Dasar: Dampak Model Project Based Learning Model. DIDAKTIKA TAUHIDI: Jurnal Pendidikan Guru Sekolah Dasar, 7(1), 43-53.

Kubiatko dan Vaculova. (2011). Project-based learning: characteristic and the experiences with application in the sciece subject. Masaryk university.

Kusumaningrum, S., \& Djukri, D. (2016). Developing a Learning Kit with Project Based Learning Model (pjbl) to Improve Scientific Process Skills and Creativity. Jurnal Inovasi Pendidikan IPA, 1(1), 241-251. doi.org/10.21831/jipi.v2i2.5557

Komalasari, K. (2010). Pembelajaran kontekstual konsep dan aplikasi. Bandung: Refika Aditama.

Lestari, R., \& Rahayu, Y. S. (2020). Validitas lembar kegiatan peserta didik (lkpd) berbasis project based learning materi pertumbuhan dan perkembangan untuk melatih keterampilan ecopreneurship peserta didik kelas XII SMA. Berkala Ilmiah Pendidikan Biologi (BioEdu), 9(3), 516-524.

Mahardiningrum, A. S., \& Ratu, N. (2018). Profil pemecahan masalah matematika siswa smp pangudi luhur salatiga ditinjau dari berpikir kritis. Mosharafa: Jurnal Pendidikan Matematika, 7(1), 75-84.

Muhammad, M., Rahadian, D., \& Safitri, E. R. (2017). Penggunaan digital book berbasis android untuk meningkatkan motivasi dan keterampilan membaca pada pelajaran bahasa arab. Pedagogia, 15(2), 170-182. doi.org/10.17509/pedagogia.v15i2.8094

Murray \& Anna, C. R. (2017). The writing process: writing a response or reaction paper. Writing Center, Hunter College, City University Of New York

Nirwana, M., Nur, M., \& Jatmiko, B. (2021). The Problem-Solving Skills Profile of Tsanawiyah Islamic School Students in the Vibration, Wave, and Sound Learning Materials. IJORER: International Journal of Recent Educational Research, 2(2), 158-170. doi.org/10.46245/ijorer.v2i2.86

Nurhasikin, N., Ningsih, K., \& Titin, T. (2020). Pengembangan modul berbasis discovery learning materi struktur dan fungsi jaringan tumbuhan sma. Jurnal Pendidikan Informatika dan Sains, 8(2), 163-178. hdoi.org/10.31571/saintek.v8i2.1223

Nyeneng, I. D. P., \& Suana, W. (2018). Pengembangan perangkat flipped classroom pada mata pelajaran fisika SMA. Jurnal Pendidikan Fisika,6(2), 159-174. doi.org/10.24127/jpf.v6i2.1193

Rahmawati, D., KN, A. R., Rifqiawati, I., \& Lestari, I. D. (2021). Analisis perangkat pembelajaran biologi SMA dalam mengembangkan keterampilan pemecahan masalah siswa. BIODIK, 7(01), 23-32. doi.org/10.22437/bio.v7i01.11249

Restiyowati, I. (2012). Pengembangan e-book interaktif pada materi kimia semester genap kelas XI SMA. Unesa Journal of Chemical Education,1(1), 130-135. doi.org/10.26740/ujced.v1n1.p\%25p

Riyadi \& Rahayu, Y. S. (2017). Strengthening the 21st century skills of elementary school students throught the implementation of project based learning. Adnvances in Social Science, Education and Humanities Research (ASSEHR), 108(1), 253-255. doi.org/10.2991/soshec-17.2018.50

Riduwan. (2013). Skala Pengukuran Variabel-Variabel Penelitian. Bandung: Alfa Beta.

Rosida, R., Fadiawati, N., \& Jalmo, T. (2017). Efektivitas penggunaan bahan ajar e-book interaktif dalam menumbuhkan keterampilan berpikir kritis siswa. Jurnal Pembelajaran Fisika, 5(1). 
The Development of E-Book Based On Project Based Learning On The Plant Anatomy Structure Material

Safaruddin, Degeng, I. N. S., Setyosari, P., \& Murtadho, N. (2020). The effect of PJBL with WBL media and cognitive style on students' understanding and scienceintegrated concept application. Jurnal Pendidikan IPA Indonesia, 9(3), 384-395. https://doi.org/10.15294/jpii.v9i3.24628

Safaruddin, S., Ibrahim, N., Juhaeni, J., Harmilawati, H., \& Qadrianti, L. (2020). The Effect of Project-Based Learning Assisted by Electronic Media on Learning Motivation and Science Process Skills. Journal of Innovation in Educational and Cultural Research, 1(1), 22-29. https:/ / doi.org/10.46843/jiecr.v1i1.5

Sadiman. (2008). Interaksi dan Motivasi Belajar Mengajar. Jakarta: Raja Grafindo Persada.

Sari, V. I. (2017). Tingkat Keterbacaan Buku Teks Bahasa Indonesia Jenjang Smp Menggunakan Teori Fry. Jurnal Penelitian Pendidikan Indonesia, 2(3), 1-5.

Saputri, J. R., \& Mampouw, H. L. (2018). Kemampuan pemecahan masalah dalam menyelesaikan soal materi pecahan oleh siswa SMP ditinjau dari tahapan Polya. Math Didactic: Jurnal Pendidikan Matematika,4(2), 146-154. doi.org/10.33654/math.v4i2.104

Serin, H. (2019). Project based learning in mathematics context. International Journal of Social Sciences E Educational Studies, 5(3), 232-236. doi.org/10.23918/ijsses.v5i3p232

Setiawan, L., Wardani, N. S., \& Permana, T. I. (2021). Peningkatan kreativitas siswa pada pembelajaran tematik menggunakan pendekatan project based learning. Jurnal Basicedu, 5(4), 1888-1898. doi.org/10.31004/basicedu.v5i4.1068

Searmadi, B. P. H. (2016). Penerapan inovasi flipbook sebagai media pembelajaran untuk meningkatkan hasil belajar pengenalan php kelas XI RPL di SMK negeri 2 Mojokerto. IT-Edu: Jurnal Information Technology and Education, 1(02), 42-48.

Sumarmi. (2012). Model-model pembelajaran geografi. Yogyakarta: Aditya Media

Taylor, L. (1993). Vygotskian influences in mathematics education, with particular reference to attitude development. Journal Focus on learning problems in mathematics, 15(2), 3-17.

The George Lucas Educational Foundation. (2005). Instructional Module Project Based Learning. Edutopia.

Thiagarajan, S., Semmel, D. S., \& Semmel, M. I. (1974). Instructional development for training teacher of exceptional children. Bloomington Indiana: Indiana University.

Wahida, F., Rahman, N., \& Gonggo, T. (2015). Pengaruh model pembelajaran berbasis proyek terhadap keterampilan berpikir kreatif dan hasil belajar siswa kelas X SMA Negeri 1 Parigi. Jurnal Sains dan Teknologi Tadulako, 4(3), 6-43.

Wijaya, E. Y., Sudjimat, D. A., Nyoto, A., \& Malang, U. N. (2016). Transformasi pendidikan abad 21 sebagai tuntutan pengembangan sumber daya manusia di era global. Prosiding Seminar Nasional Pendidikan Matematika, 1(26), 263-278.

Zamanian, M., \& Heydari, P. (2012). Readability of texts: State of the art. Theory $\mathcal{E}$ Practice in Language Studies, 2(1), 43-53. doi.org/10.4304/tpls.2.1.43-53

*Desy Muwaffaqoh (Corresponding Author)

Universitas Negeri Surabaya,

Postgraduate Programme, Science Education Study Program

Continuing Program Development, Jl. Unesa Lidah Wetan, Surabaya, East Java, Indonesia.

Email: desy.19007@mhs.unesa.ac.id 
The Development of E-Book Based On Project Based Learning On The Plant Anatomy Structure Material

Prof. Dr. dr. Tjandra Kirana, M.S., Sp.And.

Universitas Negeri Surabaya,

Postgraduate Programme, Science Education Study Program

Continuing Program Development, Jl. Unesa Lidah Wetan, Surabaya, East Java, Indonesia

Email: nana.snoer@gmail.com

Prof. Dr. Fida Rachmadiarti, M.Kes.

Universitas Negeri Surabaya,

Postgraduate Programme, Science Education Study Program

Continuing Program Development, Jl. Unesa Lidah Wetan, Surabaya, East Java, Indonesia

Email: fidarachmadiarti@unesa.ac.id 